\title{
Renal Glycogen Content and Hormonal Control of Enzymes Involved in Renal Glycogen Metabolism
}

\author{
EVELYNE DELAVAL, ${ }^{(27)}$ EVELYNE MOREAU, SOLOMANDIMBINIRINA ANDRIAMANANTSARA, \\ AND JEAN-PIERRE GELOSO
}

Laboratoire de Différenciation Fonctionnelle, Université Paris 7, F - 75251 Paris Cedex 05 France

\begin{abstract}
Summary
Fetal rat kidney showed glycogen deposition that reached a maximal value of $60 \mu \mathrm{g} \cdot \mathrm{mg}$ prot $^{-1}$ on day 18 and declined thereafter. At birth glycogen concentration is reduced $(20 \mu \mathrm{\mu g} \cdot \mathrm{mg}$ prot $^{-1}$ ) but higher than adult one (cortex, $2.2 \mu \mathrm{g} \cdot \mathrm{mg} \mathrm{prot}^{-1}$ and medulla, $3.4 \mu \mathrm{g} \bullet \mathrm{mg}$ prot $^{-1}$ ). From day 17 to the birth, ghycogen synthetase and phosphorylase activities increased slowly except for acid glucosidase activity which increased rapidly between day 18 to the birth (3-fold). Corticosteroid deprivation had no effect upon glycogen content but fetal decapitation on day 16 reduced glycogen content in kidney of 19-day-old fetuses.
\end{abstract}

In the adult kidney, the concentration of glycogen, which is mainly localized in collecting ducts $(18,20)$ is extremely low compared with other organs such as liver, heart of muscle. Glycogen turnover rate is more rapid in the medulla than in the cortex (18). It has been observed in several species $(2,15,25)$ that the glycogen concentration in kidneys of newborn animals is relatively high and as far as we know, no data are available in the fetus. In the rat, Dicker and Shirley (8) have made a correlation between the progressive disappearance of renal glycogen during the 2-3 wk after birth and an initially high rate of anaerobic glycolysis that subsequently decreases to levels found in the adult. According to these authors the major source of ATP in neonatal kidney is anaerobic glycolysis whereas aerobic glycolysis predominates in the adult. Consequently, an increased glucose requirement, which may be supplied by glycogen mobilization, may be expected in the kidney of young rats. The differentiation of rat kidney is known to take place a few days before birth $(6,21)$. Assuming that renal glycogen may play an important role in providing energy for differentiation and maturation during the perinatal period, we studied the evolution of renal glycogen concentration in relationship to enzyme activities involved in glycogen metabolism in fetal and newborn rats. In addition an eventual endocrine control of glycogen metabolism was also investigated.

\section{MATERIALS AND METHODS}

The female rats used in these experiments were of the Sherman strain whose length of gestation was 21 days. Fetuses between 1621 days of gestation were used.

\section{EXPERIMENTAL PROCEDURES}

Maternal adrenalectomy and metopirone treatment. In order to suppress corticosteroids in fetal plasma, maternal adrenalectomy was associated with metopirone treatment as previously described (10). Maternal adrenalectomy was performed at days 15 or 16 of gestation. Pregnant rats were then injected subcutaneously with metopirone at a dose of $10 \mathrm{mg}$ twice daily until sacrifice (days 18 or 21). Metopirone, which has been kindly supplied by CIBA laboratory, is a steroid hydroxylase inhibitor crossing the placental barrier. The effectiveness of treatment was routinely controlled by verifying the enlargement of the fetal adrenal glands. Fetuses of adrenalectomized-treated mothers were compared with "control" fetuses of sham-operated mothers.

Fetal decapitation. Hypothalamo-hypophyseal and thyroparathyroid hormones of fetuses were suppressed by total decapitation according to the technique of Jost (16), either at day 16 or day 18 of gestation. Fetuses were removed at days 19 or 21 , respectively.

\section{ANALYTICAL PROCEDURES}

Mothers were killed by cervical fracture and fetal and maternal kidneys were quickly removed. Cortex was separated from medulla in adult tissue only. Kidney, adult cortex and medulla were frozen in liquid $\mathrm{N}_{2}$ and kept at $-20^{\circ} \mathrm{C}$.

Glycogen content. Kidneys were homogenized in $0.03 \mathrm{~N} \mathrm{HCl}$ with a Potter-Teflon glass homogenizer. One hundred $\mu$ l of homogenate were spread on pieces of filter paper (Whatman 3M Chromatography paper) according to the technique described by Chan and Exton (4). After hydrolysis of glycogen by amyloglucosidase, glucose liberated in the incubation medium was specifically determined with hexokinase and glucose-6-phosphate dehydrogenase (17). The increase in NADPH was measured by the change in extinction at $340 \mathrm{~nm}$. Glycogen content was expressed as microgram of glycogen per milligram of protein or as microgram of glycogen content per kidney.

Glycogen symthetase (EC 2.4.1.11). Glycogen synthetase was determined according to De Wulf and Hers (7) from UDP-U $-\left[{ }^{14} \mathrm{C}\right]$ glucose. Two activities were measured: total enzyme activity (form $\mathrm{a}+\mathrm{b}$ ) and active synthetase activity (form a) only, with $10 \mathrm{mM}$ sulfate as stimulator (7). Enzyme activity was expressed as nanomoles of UDP-U- $\left[{ }^{14} \mathrm{C}\right]$ glucose incorporated into glycogen per milligram of protein and per minute of incubation (nmole $\cdot \mathrm{mg}$ $\left.\operatorname{prot}^{-1} \cdot \min ^{-1}\right)$.

Glycogen phosphorylase (EC 2.4.1.1). The activity of active glycogen phosphorylase was determined in the direction of glycogen synthesis (14). Inorganic phosphate liberated in the incubation medium was measured by the technique of Chen et al. (5) and corrected for endogenous inorganic phosphate and noncatalytic breakdown of GIP. Enzyme activity was expressed as nanomoles of $P_{i}$ liberated per milligram of protein and per minute of incubation (nmole $\mathrm{Pi} \cdot \mathrm{mg} \mathrm{prot}^{-1} \cdot \mathrm{min}^{-1}$ ).

Lysosomal (amylo 1-4) glucosidase (EC 3.2.1.20). Kidneys were homogenized in ice cold distilled water. The lysosomal fraction was disrupted by three freezings and thawings. The incubation mixture for acid glucosidase contained $20 \mathrm{mM}$ of $p$-nitrophenyl$\alpha$-glucoside in $0.1 \mathrm{M}$ citrate buffer, $\mathrm{pH}-4.5$ (22). Acid glucosidase activity was expressed as nanomoles of $p$-nitrophenol produced

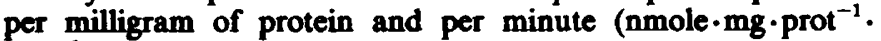
$\min ^{-1}$ ).

Protein content was estimated by the method of Lowry et al. 


\section{STATISTICAL METHODS}

Results were expressed as means \pm standard error of the mean and the data were analyzed using Student's unpaired $t$ test.

\section{RESULTS}

Glycogen content. The glycogen concentration of fetal kidneys measured in total homogenate increased from day 16 to day 18 to reach a value 20 times higher than in adults (Fig. 1). After this time, the glycogen concentration declined to reach the value of 24 $\mu \mathrm{g} \cdot \mathrm{mg}_{\mathrm{grot}} \mathrm{pr}^{-1}$ on day 21 and at birth a further decrease occurred. In the adult kidney, glycogen concentration was low: medulla, $3.43 \pm 0.68 \mu \mathrm{g} \cdot \mathrm{mg} \operatorname{prot}^{-1}(7$ cases) and cortex, $2.20 \pm 0.24 \mu \mathrm{g}$. $\mathrm{mg} \operatorname{prot}^{-1}$ (13 cases). Because kidney weight and kidney protein increased during the fetal period studied and more particularly from days 18 to 21 , it was interesting to compare glycogen concentration with glycogen content per kidney (Fig. 1). The values were calculated using the mean of glycogen concentration and the mean of kidney protein for each fetal age. Glycogen content in fetal kidney markedly increased from days 17 to 20 , after this stage the glycogen deposition was very slow.

Activities of enzymes of glycogen metabolism. The activities of glycogen synthetase a, phosphorylase a and acid glucosidase are indicated in Figure 2 . In fetuses, glycogen synthetase a activity increased slowly from day $17\left(0.16 \pm 0.01 \mathrm{nmole} \cdot \mathrm{mg} \mathrm{prot}^{-1}\right.$. $\left.\min ^{-1}, n=5\right)$ to day $21\left(0.26 \pm 0.03 \mathrm{nmole} \cdot \mathrm{mg} \mathrm{prot}^{-1} \cdot \mathrm{min}^{-1}, n\right.$ $=9$ ). Glycogen synthetase $(a+b$ form) activity showed the same evolution, respectively: $0.51 \pm 0.08 \mathrm{nmole} \cdot \mathrm{mg} \mathrm{prot}^{-1} \cdot \mathrm{min}^{-1}(n=$ 6) to $0.66 \pm 0.11 \mathrm{nmole} \cdot \mathrm{mg} \operatorname{prot}^{-1} \cdot \min ^{-1}(n=7)$. The activity of glycogen phosphorylase a increased slightly but significantly between day $17\left(10.1 \pm 1.5 \mathrm{nmole} \cdot \mathrm{mg} \mathrm{prot}^{-1} \cdot \mathrm{min}^{-1}, n=9\right)$ and day $21\left(14.0 \pm 1.0 \mathrm{nmole} \cdot \mathrm{mg} \mathrm{prot}^{-1} \cdot \min ^{-1}, n=9\right)$. Acid glucosidase activity remained constant until day 18 of gestation and then progressively increased to reach a level similar to the adult one. At birth and $24 \mathrm{~h}$ after birth, a clear increase in all enzymes activities was observed.

In Table 1, cortex and medulla activities of adult kidney were reported. Glycogen synthetase (form a and form $a+b$ ) activities were higher in medulla than in cortex whereas activities of glycogen degradation were either constant (phosphorylase) or lower than those of cortex (acid glucosidase).

Effect of maternal adrenalectomy and metopirone treatment (Table 2). The suppression of the source of corticoids available for
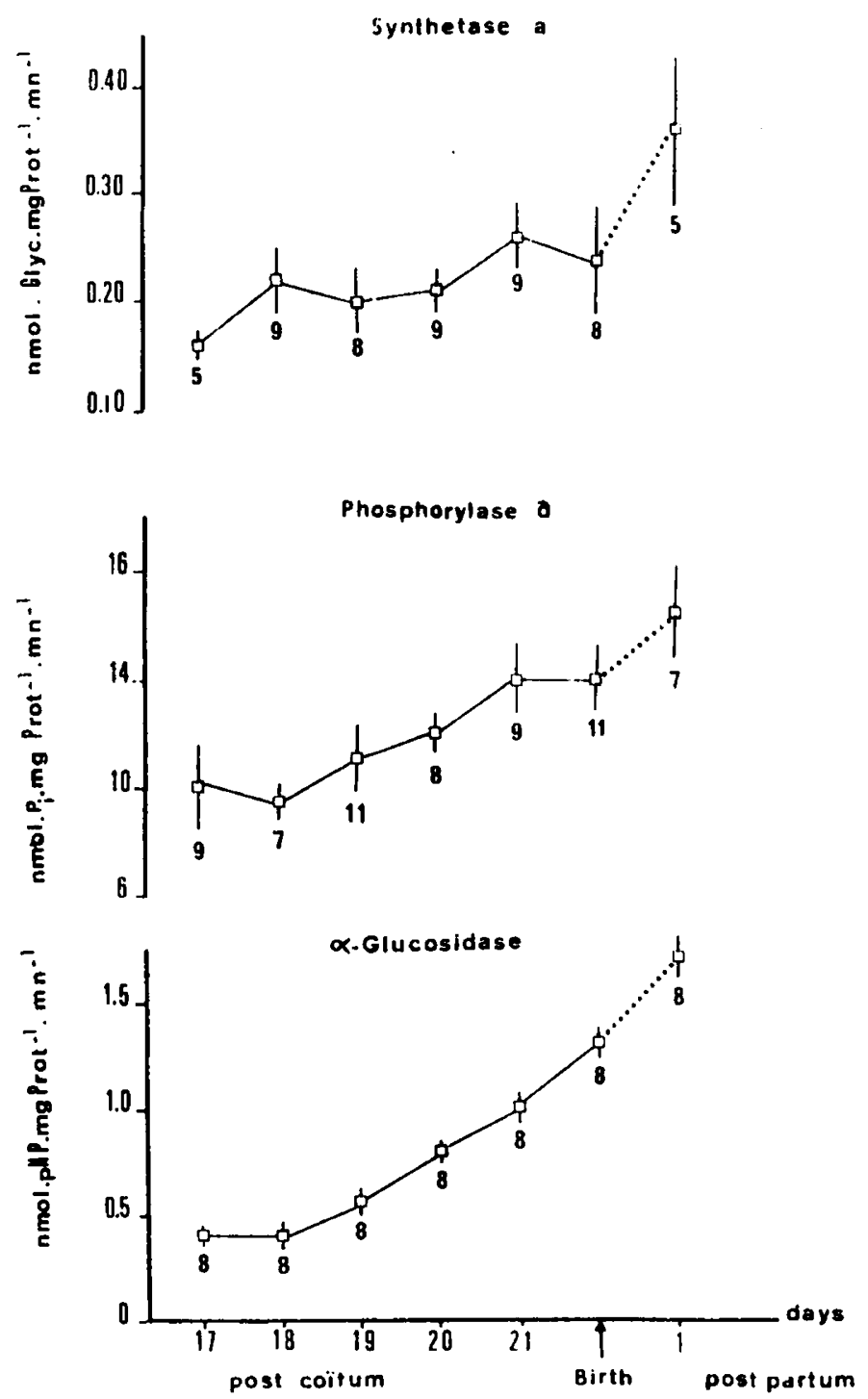

Fig. 2. Changes in enzymatic activities of glycogen metabolism in fetal and neonatal rat kidneys.

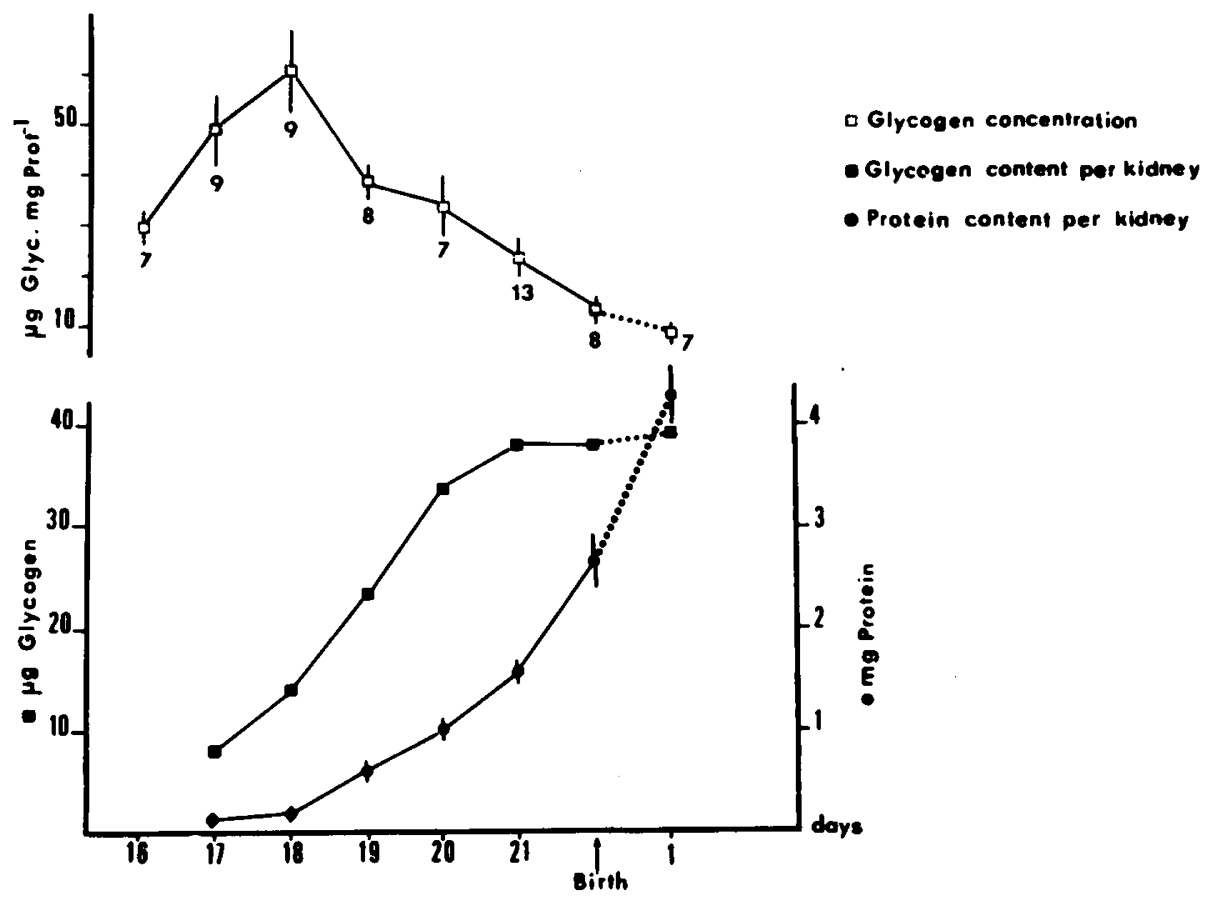

Fig. 1. Changes in glycogen concentration, glycogen content per kidney, and protein content per kidney in fetal and neonatal rat. 
fetuses had no effect on glycogen concentration regardless of the age at which treatment was started (day 15 or day 18 of gestation).

Effect of fetal decapitation. The absence of the hypothalamohypophyseal axis did not impair the normal glycogen deposition occurring between days 16 and 18 of gestation: control, $62.4 \pm 7.9$ $\mathrm{ng} \cdot \mathrm{mg} \operatorname{prot}^{-1}, n=5$ and decapitated fetuses, $57.1 \pm 7.5 \mathrm{ng} \cdot \mathrm{mg}$ $\operatorname{prot}^{-}, n=5$. On day 19 of gestation the glycogen concentration as well as glycogen content in kidneys of decapitated fetuses was lower than that of control fetuses (Table 3) without any detectable change in enzyme activities of glycogen metabolism. Acid glucosidase activity was unchanged: control, $0.50 \pm 0.03 \mathrm{nmole} \cdot \mathrm{mg}$ $\operatorname{prot}^{-1} \cdot \min ^{-1}, n=4$ and decapitated, $0.51 \pm 0.01 \mathrm{nmole} \cdot \mathrm{mg} \mathrm{prot}{ }^{-1}$. $\mathrm{mn}^{-1}, n=4$.

\section{DISCUSSION}

During fetal life, renal glycogen evolves through two distinct periods. Between days 16 and 18 of gestation, there is a marked increase in glycogen concentration (2-fold); from day 18 onwards, concentration decreases to reach the low value observed in adults. A similar evolution of glycogen concentration has been described

Table 1. Glycogen enzyme activities in adult rat kidney ${ }^{1}$

\begin{tabular}{|c|c|c|}
\hline & Cortex & Medulla \\
\hline \multicolumn{3}{|c|}{$\begin{array}{l}\text { Glycogen synthetase (nmole }\left[{ }^{14} \mathrm{C}\right] \text { gly- } \\
\text { cogen } \cdot \mathrm{mg} \text { protein }{ }^{-1} \cdot \mathrm{mm}^{-1} \text { ) }\end{array}$} \\
\hline Form $a+b$ & $\begin{array}{l}0.38 \pm 0.04 \\
(12)\end{array}$ & $\begin{array}{l}0.64 \pm 0.10^{2} \\
(3)\end{array}$ \\
\hline Form a & $\begin{array}{l}0.05 \pm 0.01 \\
\quad(11)\end{array}$ & $\begin{array}{l}0.19 \pm 0.01^{2} \\
\text { (3) }\end{array}$ \\
\hline $\begin{array}{l}\text { Glycogen phosphorylase } \\
\left(\text { nmole } \mathrm{P}_{\mathrm{i}} \cdot \mathrm{mg} \text { protein }\right. \\
\left.-1 \cdot \min ^{-1}\right)\end{array}$ & $\begin{array}{c}4.1 \pm 0.6 \\
(7)\end{array}$ & $\begin{array}{c}6.1 \pm 1.8 \\
(4)\end{array}$ \\
\hline $\begin{array}{l}\text { Lysosomal acid glucosidase } \\
\text { (nmole } \cdot \mathrm{mg} \text { protein } \\
\left.-1 \cdot \min ^{-1}\right)\end{array}$ & $\begin{array}{c}2.0 \pm 0.1 \\
(8)\end{array}$ & $\begin{array}{l}1.3 \pm 0.1^{2} \\
(8)\end{array}$ \\
\hline
\end{tabular}

' Values are means \pm S.E.; numbers in parentheses refer to the number of observations.

${ }^{2}$ Significantly different from cortex $P<0.05$. in other organs (see for instance $1,19,23$ ). In lung and heart, the decline in concentration is interpreted as a mobilization of the glycogen store. Such an interpretation cannot be applied to fetal kidney because the total glycogen content ( $\mu g$ glycogen by kidney) increases throughout the period studied indicating continuous glycogen deposition. There is, however, a notable change in the rate of deposition that is high between days 16 and 20 and markedly slowed from day 20 onwards as shown by the reduction of the slope of the glycogen content curve. The pattern of glycogen concentration evolution results from the variations of two parameters: the rate of glycogen deposition and the kidney protein content. Because during the last days of gestation a slow rate of glycogen deposition is concomitant with a sharp increase in protein content (Fig. 1), the decline in glycogen concentration must be interpreted as a glycogen dilution by proteins, which completely masks the slight increase in glycogen content. In neonatal rat kidney, glycogen content is particularly abundant in collecting ducts $(2,25)$. In fetal rat kidney, we controlled the localization of glycogen: PAS-positive material observed in most of the cells of collecting ducts disappeared after amyloglucosidase treatment (data not shown).

It appears that, in the kidney, glycogen synthesis always predominates glycogen degradation at all stages of development, but from day 20 of gestation onwards, a new equilibrium is established between synthesis and catabolism. This new equilibrium may be due either to a relative decrease in synthesis or an increase in catabolism or both. Neither the development of glycogen synthetase activity nor that of phosphorylase activity can explain the change in glycogen deposition rate because these two enzyme activities concomitantly increase during the fetal period of life. It has been suggested (13) that, in the liver, acid glucosidase plays a notable role in glycogen hydrolysis.

In the fetal rat lung, acid glucosidase seems to be responsible (with phosphorylase) for glycogen breakdown (3). The present results show that in fetal kidney, acid glucosidase activity sharply increases from day 19 onwards. This finding must be related to the presence of profuse large endocytic vesicles close to lysosomelike bodies in the proximal tubule cells on day 20 of gestation (21). In adult kidney, glycogen deposition is higher in the medulla than in the cortex and could be due to a more important glycogen

Table 2. Effects of maternal adrenalectomy and metopirone treatment on adrenal gland weight and glycogen concentration of fetal kidney

\begin{tabular}{|c|c|c|c|c|}
\hline & \multicolumn{2}{|c|}{ Day $18^{2}$} & \multicolumn{2}{|c|}{ Day $21^{3}$} \\
\hline Glycogen concentration $\left(\mu \mathrm{g} \cdot \mathrm{mg}\right.$ protein $\left.{ }^{-1}\right)$ & $\begin{array}{c}57.52 \pm 6.97 \\
(9)\end{array}$ & $\begin{array}{c}48.81 \pm 4.97 \\
(5)\end{array}$ & $\begin{array}{l}23.97 \pm 2.77 \\
(13)\end{array}$ & $\begin{array}{c}23.64 \pm 3.91 \\
(9)\end{array}$ \\
\hline $\begin{array}{l}\text { Adrenal gland weight (mg. } 100 \mathrm{~g}^{-1} \text { fetal } \\
\text { body weight) }\end{array}$ & $\begin{array}{c}104 \pm 4 \\
(4)\end{array}$ & $\begin{array}{c}124 \pm 3^{4} \\
\text { (11) }\end{array}$ & $\begin{array}{c}49 \pm 2 \\
(7)\end{array}$ & $\begin{array}{c}79 \pm 2^{4} \\
(8)\end{array}$ \\
\hline
\end{tabular}

\footnotetext{
'Values are means \pm S.E.; numbers in parentheses refer to the number of observations.

${ }^{2}$ Maternal adrenalectomy was performed on day 15 of gestation and metopirone was injected twice a day (20 mg) until sacrifice. Fetuses were removed on day 18.

${ }^{3}$ Maternal adrenalectomy was performed on day 18 of gestation and metopirone was injected twice a day (20 mg) until sacrifice on day 21.

Significantly different from control $P<0.05$.
}

Table 3. Effects of the absence of hypothalamo-hypophyseal hormones on glycogen concentration, glycogen content, and enzyme activities of 19-day-old fetuses ${ }^{1}$

\begin{tabular}{|c|c|c|c|c|c|}
\hline & \multicolumn{2}{|c|}{ Glycogen } & \multicolumn{2}{|c|}{ Glycogen synthetase } & $\begin{array}{c}\text { Phosphorylase } \\
\begin{array}{c}\left(\text { nmole } \mathbf{P}_{\mathrm{i}} \cdot \mathrm{mg}\right. \\
\left.\text { protein }^{-1} \cdot \mathrm{min}^{-1}\right)\end{array}\end{array}$ \\
\hline Control & $\begin{array}{c}33.29 \pm 2.59 \\
(8)\end{array}$ & $\begin{array}{c}16.9 \pm 1.8 \\
(8)\end{array}$ & $\begin{array}{c}0.23 \pm 0.06 \\
\text { (3) }\end{array}$ & $\begin{array}{l}0.92 \pm 0.08 \\
\text { (3) }\end{array}$ & $\begin{array}{c}17.2 \pm 0.8 \\
\text { (3) }\end{array}$ \\
\hline Decapitated fetuses & $\begin{array}{c}23.8 \pm 1.75^{2} \\
(7)\end{array}$ & $\begin{array}{c}9.6 \pm 1.2^{2} \\
(7)\end{array}$ & $\begin{array}{c}0.24 \pm 0.02 \\
\text { (3) }\end{array}$ & $\begin{array}{c}0.72 \pm 0.06 \\
(3)\end{array}$ & $\begin{array}{l}17.9 \pm 1.9 \\
(4)\end{array}$ \\
\hline
\end{tabular}

\footnotetext{
${ }^{1}$ Values are means \pm SE; numbers in parentheses refer to the number of observations.

${ }^{2}$ Significantly different from controls.
} 
synthetase activity and a lower acid glucosidase activity in the cortex than in the medulla. It is tempting to hold the development of acid glucosidase activity responsible for the change in glycogen deposition rate.

In fetal rat kidney, glycogen catabolism might lead, besides to the glycolytic pathway, to glucose production because glucose-6phosphatase activity markedly increases during the last days of gestation allowing a glucose release from gluconeogenesis (6). In the absence of clear glycogen mobilization either in late fetuses (as in lung) or at birth (as in liver), it seems doubtful that glycogen plays an important role as a source of energy for the kidney during the perinatal period. Recently, we have shown that glucose does not seem to play a major role in oxydative metabolism of fetal kidney (9). That does not exclude, however, the possibility that renal glycogen constitutes an energy store available to the kidney in particular situations such as fetal caloric deprivation after maternal fasting.

It is well known that hepatic glycogen metabolism in fetuses is under hormonal control: corticoids stimulate glycogen synthetase activity and glucagon like growth hormone enhance phosphorylase activity $(11,12,24)$. Growth hormone also appears to stimulate phosphorylase development in the rat fetal lung (3). Glycogen breakdown, in this organ, seems to be controlled by corticosteroids through autophagic activity (3).

Present results show that in fetal rat kidney a lack (or marked decrease) of circulating corticosteroids has no effect on the glycogen deposition rate. This is in agreement with previous observations in fetal mice (23) showing that, administration of dexamethasone does not change the renal glycogen concentration. It can be assumed that glycogen deposition in fetal kidney is not controlled by corticosteroids. Three days after decapitation, which occurred on day 16 of gestation, there was a slight but significant decrease in glycogen concentration as well as in glycogen content without any change in enzyme activities. This might be due to trophic trouble resulting from a disturbance of blood circulation. Another possibility is an increase in the autophagic capacity of renal tissue in decapitated fetuses (due to a higher fragility of lysosomes). Whatever the cause of this glycogen decrease, we can conclude that glycogen metabolism in fetal rat kidney is not under direct hormonal control.

\section{REFERENCES AND NOTES}

1. Ballard, F. J. and Oliver, I. T.: Glycogen metabolism in embryonic chick and neonatal rat liver. Biochim. Biophys. Acta, $71: 578$ (1963).

2. Bogomolova, N. A.: Age changes in kidney of the white rat. Arkh. Anat. Gistol. Embriol., 48: 80 (1965).

3. Bourbon, J. and Jost, A.: Control of glycogen metabolism in the developing fetal lung. Pediatr. Res., 16: 50 (1982).

4. Chan, T. M. and Exton, J.: A rapid method for the determination of glycogen content and radioactivity in small quantities of tissue or isolated hepatocytes.
Anal. Biochem., 71: 96 (1975).

5. Chen, P. S., Toribara, T. Y. and Warner, H.: Microdetermination of phosphorus. Anal. Chem., 28: 1756 (1956).

6. Delaval, E., Moreau, E., and Geloso, J. P.: Development of ammonia and glucose productions from glutamine in foetal rat kidney: effects of metabolic acidosis. Pflügers Arch. Eur. J. Physiol., 379: 95 (1979).

7. De Wulf, H. and Hers, H. G.: The interconversion of liver glycogen synthetase $a$ and $b$ in vitro. European J. Biochem., 6: 552 (1968).

8. Dicker, S. E. and Shirley, D. G.: Rates of oxygen consumption and of anaerobic glycolysis in renal cortex and medulla of adult and new-born rats and guinea pigs. J. Phyșiol., 212: 235 (1971).

9. Freund, N., Sedraoui, M., and Geloso, J. P.: Oxidative metabolism in feotal rat kidney during late gestation. Accepted for publication in J. Develop. Physiol. (London), (1982).

10. Geloso, J. P. and Bassett, J. C.: Role of adrenal glands in development of foetal rat kidney Na-K-ATPase. Pflugers Arch. Eur. J. Physiol., 348: 105 (1974).

11. Gilbert, M. and Vaillant, R.: Contrôle de la synthèse du glycogène dans le foie foetal de rat. Biochimie, 57: 597 (1975).

12. Girard, J. R. Caquet, D., Bal, D. and Guillet, I.: Control of rat liver phosphorylase, glucose-6-phosphatase and phosphoenolpyruvate carboxykinase activities by insulin and glucagon during the perinatal period. Enzyme, 15: 272 (1973).

13. Girard, J. R., Ferre, P., and Gilbert, M.: Le Metabolisme énergétique pendant la période périnatale. Diabète et Métabolisme (Paris), 1: 241 (1975).

14. Hue, L., Bontemps, F., and Hers, H. G.: The effect of glucose and of potassium ions on the interconversion of the two forms of glycogen phosphorylase and of glycogen synthetase in isolated rat liver preparations. Biochem. J., 152: 105 (1975).

15. Isselhard, W., Fischer, J. H., Kapune, H., and Stock, W.: Metabolic patterns of several tissues of rabbits and guinea pigs during postnatal development. Biol. Neonate, 22: 201 (1973).

16. Jost, A.: Expériences de décapitation de l'embryon de lapin. C. R. Acad. Sci (Paris), 225: 322 (1947).

17. Keppler, D. and Decker K.: Glycogen. Determination with amyloglucosidase. in Methods of enzymatic analysis, Vol. 3. pp 1127-1131. (H. U. Bergmeyer, New York, 1974).

18. Lee, J. B., Vance, V. K., and Cahill. Jr. G. E.: Metabolism of ${ }^{14} \mathrm{C}$ labeled substrates by rabbit kidney cortex and medulla. Am. J. Physiol., 203: 27 (1962).

19. Maniscalco, W. M., Wilson, C. M., Gross, I., Gobran, L., Rooney, S. A., and Warshaw, J. B.: Development of glycogen and phospholipid metabolism in fetal and newborn rat lung. Biochim. Biophys. Acta, 530: 333 (1978).

20. Needleman, P., Passonneau, J. V., and Lowry, O. H.: Distribution of glucose and related metabolites in rat kidney. Am. J. Physiol., 215: 655 (1968).

21. Schaeverbeke, J. and Cheignon, M.: Differentiation of glomerular filter and tubular reabsorption apparatus during foetal development of the rat kidney. J. Embryol. Exp. Morph., 58: 157 (1980).

22. Torres, H. N. and Olavarria, J. M.: Liver- $\alpha$-glucosidases. J. Biol. Chem., 239: 2427 (1963).

23. Tye, L. M. and Burton, A. F.: Glycogen deposition in fetal mouse tissues and the effect of dexamethasone. Biol. Neonate, 38: 265 (1980).

24. Vaillant, R. Personal communication.

25. Wake, C. J., Moffat, D. B., Creasey, M. and Clague, H. W.: Studies on the postnatal development of the collecting ducts of the rat kidney, with particular reference to their glycogen content. Acta Anatomica, 89: 1 (1974).

26. Lowry, O. H., Rosebrough, N. J., Farr, A. L., and Randall, R. J.: Protein measurement with Folin phenol reagent. J. Biol. Chem., 193: 265 (1951).

27. Requests for reprints should be addressed to: Dr. Evelyne DELAVAL, Laboratoire de Différenciation Fonctionnelle, Université Paris 7, 2 Place Jussieu, F 75251 Paris Cedex 05 France.

27. Received for publication July $15,1982$.

28. Accepted for publication February 15, 1982. 